\title{
HPRT gene mutation, sister chromatid exchange and comet assay in peripheral lymphocytes of radiation laborers at Al-Amal Cancer Hospital in Baghdad
}

\author{
Maha Tareq Hussein ${ }^{1,}{ }^{*}$, Abdulsahib Kadhim Ali ${ }^{2}$ and Amel Jabbar Mutta ${ }^{3}$ \\ ${ }^{1}$ Ministry of Education, Directorate of Institutional Development and Government Coordination. Iraq, Baghdad. \\ ${ }^{2}$ Ministry of Science and Technology, Central Labs. Directorate.
}

International Journal of Biological and Pharmaceutical Sciences Archive, 2022, 03(01), 001-007

Publication history: Received on 22 November 2021; revised on 07 January 2022; accepted on 09 January 2022

Article DOI: https://doi.org/10.53771/ijbpsa.2022.3.1.0102

\begin{abstract}
A Study performed on 30 Iraqi radiation Labors had been exposed to a low dose to ionizing radiation at Al-Amal Cancer Hospital in Baghdad the use of three genetic endpoints. Covered 12 females and 18 males between the aged to (22-57) years. In addition to 20 Healthy individuals from the population, dwelling Baghdad, covered, 7 females and 13 males, aged (19 - 55) years which are non-smokers, non- alcoholic. The cytogenetic analysis, including, HPRT gene mutation, comet assay and SCE have been carried out on peripheral blood lymphocytes of labors and control groups. The HPRT gene mutation assay showed a significant increase $(\mathrm{p}<0.05)$ in the radiation labors. There were found a significant increase $(\mathrm{p}<0.05)$ in comet tail length and tail moment values in the human lymphocyte in these radiation Labors compared with the control group. Also the SCE in human lymphocyte for radiation Laborers was significantly $(\mathrm{p}<0.05)$ higher than in a control group. Results obtained confirmed the cytogenetic analysis; including, HPRT gene mutation, comet assay and SCE are useful as biodosimetric markers for the detection of human exposure to low doses of ionizing radiation. It reflects the simultaneous exposure and actual levels of DNA damage present in radiological laborers' peripheral blood leukocytes by detecting temporary DNA damage and / or repair activity.
\end{abstract}

Keywords: Ionizing radiation; Lymphocytes; HPRT gene; Comet assay; SCE

\section{Introduction}

The ionizing radiation is an omnipresent environment, a physical agent with very well-known damaging effects of DNA. Levels of exposure to ionizing radiation in hospitals have reduced in current a long time and are now properly beneath the regulatory restriction of $20 \mathrm{mSv} /$ year, and in reality nicely under the detection restrict for dosimeters. Such as nuclear medicine makes use of of radiation, and interventional procedures, might also expose persons to greater doses, and these are the troubles of problems of concern [1]. With the development of techniques in cytogenetic, human chromosomal response to ionizing radiations both, in vitro and in vivo has been investigated thoroughly. In vivo cytogenetic studies of accidental exposure to human radiation were performed and are confined to groups like people exposed to Chernobyl explosion [2,3]. Fabry-Wilmer radiation accident in Goiania, Brazil [4] assessment of chromosomal damage in Tunisian hospital workers who are under the influence of exposure to low levels of infrared radiation Fabry-Wilmer radiation accident in Goiania, Brazil [5], also evaluation of DNA damage in lymphocytes in peripheral blood of radiation labors at the site of Al-Tuwaitha [6]. Several studies of Hypoxanthine guanine phosphoribosyl transferase (HPRT) gene mutations in human cultured cells and lymphocytes in vivo have provided evidence for age, exposure and genetics influence mutation frequency [7]. An increased mutation frequency with increasing age in normal, healthy people is generally observed $[8,9]$. A commonly used analytic approach for somatic cell mutation frequencies has been widely used for background information in vivo. Acquired in children and adults who have been exposed to both known and unknown environmental mutations [10,11].

\footnotetext{
${ }^{*}$ Corresponding author: Maha T Hussein

Ministry of Education, Directorate of Institutional Development and Government Coordination. Iraq, Baghdad. 
Single-cell gel electrophoresis provides a fast and visual method for the quantitative assessment of DNA breakdown in single cells. DNA damage at the single cell level is visualized as an increased migration of genetic material ("comet tail") from the nucleus (comet head). It requires viable cells, but not growth, and can be applied to permanently differentiated cells [23]. The comet test measures the quantity of DNA fragmentation in any given person studied. This assay very sensitive and requires a researcher who is skilled at interpreting the results. This test is widely conducted when searching for genetic damage [12]. During past years, single cell gel electrophoresis or comet assay has been introduced as a useful method for human bio-monitoring studies $[13,17]$. SCE is a natural molecular process that exchanges genetic material between identical sister chromatids [18]. SCEs were likely initiated by non-repairable dual strand breaks (DSBs) that form through the G1 phase of the cell cycle. It is as well plausible that unrepaired DNA adducts induce DSBs during DNA replication when the transcription mechanism is disrupted in the approximation in $\mathrm{S}$ phase of the cell cycle. Then the DSBs are fixed through the S phase by symmetric recombination are, which leads to the formation of SCEs [19]. The objective of the current study was to assess the role of the HPRT gene mutation, DNA gel electrophoresis (comet) and SCEs as biomarkers of radiation injury for individuals professionally exposed to ionizing radiation.

\section{Material and methods}

The study involved collected 30 individuals (18 males and 12 females), which are non- smokers and non-alcoholics, (aged 22 - 57 year and the length of employment is over than 5 years) who have been exposed professionally to low level of radiation with and more than 5 length of employment during their works from laborers at Al-Amal Hospital for cancer administration in Baghdad -Iraq; also to 20 individuals (13 males and 7 females), which are non- smokers and non-alcoholics, as apparently health control aged 19-55 years. They were asked to fill in extensive questionnaire which included the following criteria (age, sex, smoking, drink alcohol, X-ray, abortion, time of living in this area, kind of their work). Three genetic parameters were studied by using the HPRT mutation, comet and SCE assays.

\subsection{Assay procedure for HPRT mutation, comet assay}

HPRT gene mutation assay was description achieved by Kassie, et,al., 2000. [20]. The DNA gel electrophoresis (comet) assay made according to description by Manual, 2001 [21].

\subsection{Microscopic examination}

Binucleate and multinucleated cells per 1000 lymphocytes in two sets of cultures were recorded under a light microscope (1000X magnification, the mutant frequency of the HPRT gene (Mf-HPRT) was calculated with the following formula [20] :

Mf-HPRT (\%o) = [(binucleated and multinucleate cells per 1000 lymphocytes when cultured with 6-TG) $\div$ (dual nucleus and multinucleated cells per 1,000 lymphocytes when cultured without 6-TG)] x 1000.A total of 100 randomly taken comets (100 from each slide) was examined using fluorescent microscope connected through camera to image analysis system. To estimate the DNA damage, the following comet parameters were assessed: tail length (TL), and tail moment (TM). The tail length (DNA migration length) is directly related and shown in micrometers to the size of the DNA fragment. It was calculated from the center of the cell. Tail moment was calculated as the product of tail length and the fraction of DNA in comet tail.

\subsection{The SCE assay}

The SCE was achieved according to the description by (IAEA, 2001)], the whole blood samples were collected from each subject .The cell cultures were incubated in RPMI-1640 culture medium (sigma) supplemented with $15 \%$ fetal bovine serum (sigma), $100 \mathrm{UI} / \mathrm{ml}$ penicillin (Sigma-Aldrich) and $0.1 \mathrm{mg} / \mu \mathrm{l}$ streptomycin (Sigma-Aldrich). Phytohemagglutinin (PHA) at a concentration $10 \mu \mathrm{l} / \mathrm{ml}$ was used to stimulate lymphocyte proliferation. In samples seeded for SCE test, the cells were cultured in the presence $10 \mathrm{mg} / \mathrm{ml}$ bromodeoxyuridine (Sigma), and incubated at $37^{\circ} \mathrm{C}$ for 72 hours. SCE sample lymphocyte cultures have been stopped with colchicine (end concentration: $16 \mathrm{mg} / \mathrm{ml}$ ) at the second mitotic division and inserted three hours before harvesting. The Differential staining of sister chromatids was performed using fluorescence-plus-Giemsa technique with Hoechst 33258 stain (Sigma) (Pfeiffer, et al., 1996). The slides of SCE were prepared, as described formerly (IAEA, 2001) one hundred cells spread in metaphases was analyzed for every subject.

\subsection{Data Analysis and Statistics}

The data of the study were compiled into the computerized data file and frequency, distribution and statistical description (Mean, SE) were divided using SPSS statistical software. Using Variance Statistical Analysis (ANOVA) test and LDS test with lower likelihood than $0.05(\mathrm{p}<0.05)$ according to. 


\section{Results and discussion}

HPRT gene mutation alkaline comet and SCEs assay were chosen as an exposure biomarker to assess continuous exposure to ionizing radiation of 30 radiation labors occupationally exposed to ionizing radiation and 20 controls. The result of the HPRT gene mutation assay in labors of Al-Amal Hospital for Cancer at Baghdad shown in table (1). The average of the Mf-HPRT (Mean \pm SE) for labors Al-Amal Hospital for cancer Administration in Baghdad -Iraq was 0.917 $\pm 0.0082 \%$, compared with the control $0.889 \pm 0.0092 \%$ (Table 1 ).

In the current study, the radioactive labors chronically exposed to ionizing radiation have been studied to cytogenetically evaluate the frequencies of HPRT gene mutation, in comparison with control individuals. It is well known that the exposure of mammalian cells to ionizing radiation produces a variety of DNA lesions, including base alterations, DNA, protein cross links, and single and double strand breaks [20]. However, it has been informed that populations exposed to ionizing radiation as well present increased frequencies of HPRT mutant frequencies of lymphocytes [22, 23, 24, 25]. The alkaline comet assay was taken as a biomarker of exposure to assess continuous exposure to ionizing radiation, 30 irradiation agents workwise exposed to ionizing radiation and 20 controls. A total of 100 randomly captured comets was examined from each slide using a fluorescent microscope connected through an image analysis system color camera. (Figure 1). Results of alkaline comet assay are brief in tables 1 which gives the mean values of tail length and tail moment for the radiation labors and control groups. The average of comet tail lengths (Mean \pm SE) in radiation labors were $18.10 \pm 0.30 \mu \mathrm{m}$, Compared the control was $14.23 \pm 0.15 \mu \mathrm{m}$. According the results obtained, the radiation labors were highly significant $(\mathrm{P}<0.05)$ compared with control groups (Table 1$)$. The average of the comet tail moment (Mean \pm SE) in radiation labors were $14.77 \pm 0.24$, when compared with the control groups were $11.44 \pm 0.20$. The observed values differed significantly $(P<0.05)$ from the tail moment values measured in control (Table 1).

Table 1 Characterization of the samples (control and radiation worker populations), and the result of frequencies of Mf- HPRT gene mutation, Comet and SCE assay on peripheral blood leukocytes of 30 radiation

\begin{tabular}{|c|c|c|c|}
\hline \multirow{2}{*}{\multicolumn{2}{|c|}{ Sample characteristics }} & \multicolumn{2}{|l|}{ Populations } \\
\hline & & Control & Radiation worker \\
\hline \multicolumn{2}{|l|}{ Number of individuals } & 20 & 30 \\
\hline \multicolumn{2}{|l|}{ Exposure time (years) $(\mathrm{X} \pm \mathrm{SD})$} & 0 & $12.48 \pm 4.71$ \\
\hline \multirow[t]{2}{*}{$\operatorname{Sex}[\mathrm{n}(\%)]$} & Male & $13(65 \%)$ & $18(60 \%)$ \\
\hline & Female & 7 ( $35 \%)$ & $12(40 \%)$ \\
\hline \multicolumn{2}{|l|}{ Age (years) (Range ) } & $19-55$ & $22-57$ \\
\hline \multirow[t]{2}{*}{ Smoking status (n, \%) } & Smokers & $0(0.00 \%)$ & $0(0.00 \%)$ \\
\hline & Non smokers & $20(100 \%$ & 30 (100 \%) \\
\hline \multicolumn{2}{|c|}{ Duration of employment (yr) (Range) } & 0 & $5-20$ \\
\hline \multicolumn{2}{|c|}{ Radiation burden over the last $5-10$ years ( Rang $\mathrm{mSv} /$ years) } & - & Less than $2 \mathrm{~m} \mathrm{~Sv} /$ years \\
\hline \multicolumn{2}{|l|}{ Mf-hprt (\%o) ( (Mean \pm SE) } & $0.889 \pm 0.0092$ & $0.917 \pm 0.0082 *$ \\
\hline \multirow{2}{*}{$\begin{array}{l}\text { Comet parameters evaluated } \\
(\text { Mean } \pm \text { SE) }\end{array}$} & Tail length $(\mu \mathrm{m})$ & $14.23 \pm 0.15$ & $18.10 \pm 0.30^{*}$ \\
\hline & Tail moment & $11.44 \pm 0.19$ & $14.77 \pm 0.24^{*}$ \\
\hline \multicolumn{2}{|l|}{ SCE /Cell (Mean \pm SE) } & $6.32 \pm 0.25$ & $7.82 \pm 0.43^{*}$ \\
\hline
\end{tabular}

The occupation contributed to the primary DNA damage levels that were recorded by lobbers at Al-Amal Cancer Hospital in Baghdad and 20 control groups for each subject* significant at $(\mathrm{P}<0.05)$. 


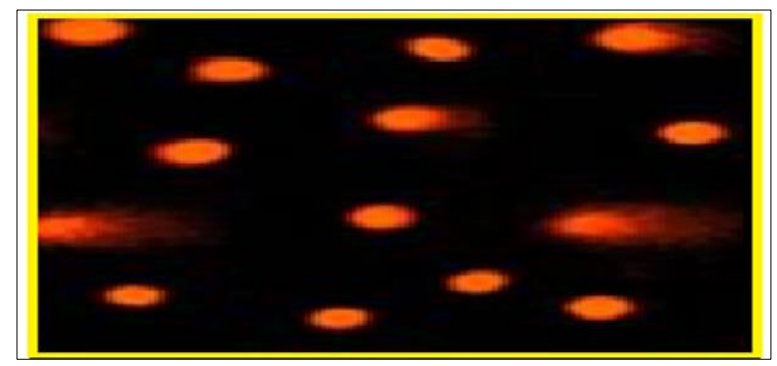

Figure 1 Microphotographs of comet in human blood cell by fluorescent microscope (400X)

The SCE was performed on peripheral blood lymphocytes obtained from 30 individuals of labors occupationally exposed low ionizing radiation doses at Al-Amal Hospital for Cancer in Baghdad then compared with 20 control individuals living in Baghdad. SCEs were scored in metaphase chromosomes were identified by fluorescent plus Giemsa staining.The mean frequencies of SCEs per cell differed significantly $(\mathrm{p}<0.05)$ between individuals of radiation labors and control, being $7.82 \pm 0.43 \mathrm{SCE} /$ cells and $6.31 \pm 0.24 \mathrm{SCE} /$ cells, respectively. However the SCE frequency was statistically significant $(\mathrm{P}<0.05)$ among radiation labors compared to control individuals. (Table 1$)$. The exposure of the human population to the environment and occupational mutants / carcinogens can be monitored using different

chemical and biological endpoints. Chromosomal aberrations, sister chromatid exchanges, and micronuclei in lymphocytes in peripheral blood for decades are on cytogenetic biomarkers that investigate risks of genotoxicity in the work environment. It has been well established that SCE arises during replication of a damaged DNA model and that the SCE assay is a sensitive method for identifying chemical and physical agents detrimental to DNA. [26]. The cumulative effect of a persistent low level ionizing radiation exposure is seen in increased frequencies of chromosomal abortions and sister chromatid exchange in radiation labors. [23].

In table 2 results of HPRT gene, SCEs, tail length and moment were recorded in peripheral blood leukocytes of physicians, technicians and engineers were highly significant $(\mathrm{P}<0.05)$ compared with control groups. While $H P R T$ gene, SCEs, tail length and moment were recorded in peripheral blood leukocytes of physicians, technicians and engineers were not statistically $(\mathrm{P}<0.05)$ due to the same working condition to all radiation groups. Among radiation labor groups, the high group mean value of HPRT gene, tail length and tail moment

Were recorded in peripheral blood leukocytes of Technicians, in peripheral blood leukocytes of engineers employed in radiation labors Al-Amal Hospital for cancer administration in Baghdad -Iraq (Table 2).

Table 2 Mean values of HPRT gene mutation, comet tail length (TL) and tail moment (TM) and SCEs for radiation worker subjects employed at Al-Amal Hospital for Cancer in Baghdad - Similar latter in a column mean there is no significant difference $(\mathrm{p}<0.050)$.

\begin{tabular}{|c|c|c|c|c|}
\hline \multirow{2}{*}{$\begin{array}{l}\text { Radiation } \\
\text { Workers sub } \\
\text { groups (No. of } \\
\text { Subjects) }\end{array}$} & \multirow{2}{*}{$\begin{array}{l}\text { Mutant } \\
\text { Frequency- } \\
\text { HPRT } \\
\text { (Mean } \pm \text { SE) } \\
\end{array}$} & \multicolumn{2}{|c|}{$\begin{array}{l}\text { Comet parameters evaluated } \\
(\text { Mean } \pm \text { SE) }\end{array}$} & \multirow[t]{2}{*}{$\begin{array}{l}\text { SCE /Cell } \\
(\text { Mean } \pm \text { SE })\end{array}$} \\
\hline & & $\begin{array}{c}\text { Tail length } \\
(\mu \mathrm{m})\end{array}$ & Tail moment & \\
\hline Physicians 13) & $0.92 \pm 0.0037 \mathrm{~b}$ & $14.92 \pm 0.21^{b}$ & $15.45 \pm 0.22^{b}$ & $7.56 \pm 0.34 \mathrm{~b}$ \\
\hline Technicians (10) & $0.93 \pm 0.0114 \mathrm{~b}$ & $15.44 \pm 0.19^{b}$ & $15.79 \pm 0.27^{b}$ & $7.49 \pm 0.39 \mathrm{~b}$ \\
\hline Engineers (7) & $0.919 \pm 0.0112 b$ & $14.82 \pm 0.23^{b}$ & $14.81 \pm 0.22^{b}$ & $7.22 \pm 0.40^{b}$ \\
\hline Control(20) & $0.889 \pm 0.0092^{\mathrm{a}}$ & $14.23 \pm 0.15^{\mathrm{a}}$ & $11.44 \pm 0.19^{a}$ & $6.31 \pm 0.24^{\mathrm{a}}$ \\
\hline
\end{tabular}

(b) is significantly different from control (a) and (b)no significant different with the Physicians, Technicians, Engineers groups ) .

Occupation effect on levels primary DNA. The increased HPRT gene, SCEs and comet values of exposed subjects in the peripheral blood leukocytes show highly significant levels of primary DNA damage as compared with controls in this study. However, the effects of unlike occupational settings and absorbed doses on the levels of DNA harm assessed with the comet assay in the majority of subjects may be excluded. Results indicate that the alkaline comet assay may be a beneficial additional complement to standard biometric methods. By detection of instantaneous DNA damage and or 
repair activity, it revers the concurrent exposure and real levels of DNA damage current in peripheral blood lymphocytes of radiological labors at the moment of blood sampling differences were not statistically.

Table 3 shown the HPRT gene mutation, comet tail length (TL) and tail moment (TM) and SCEs (Mean \pm SE) in the males and females of human lymphocyte for radiation worker subjects employed at Al-Amal Hospital for Cancer and control. Table 3 shown that the Mf-HPRT gene mutation, comet tail length and tail moment and SCEs were significantly higher $(\mathrm{P}<0.05)$ in the male and female of radiation group than the males and female of control, but the difference between female and male for Mf-HPRT gene mutation, comet tail length (TL) and tail moment (TM) and SCEs were no significant $(\mathrm{P}>0.05)$ in same group.

Table 3 HPRT gene mutation, comet tail length (TL) and tail moment (TM) and SCEs (Mean \pm SE) in the males and females of human lymphocyte for radiation worker subjects employed at Al-Amal Hospital for Cancer in Baghdad and control

\begin{tabular}{|l|c|c|c|c|c|}
\hline \multicolumn{2}{|c|}{ Studied groups } & \multirow{2}{*}{$\begin{array}{c}\text { Mutant Frequency- } \\
\text { HPRT } \\
\text { (Mean } \pm \text { SE) }\end{array}$} & \multicolumn{2}{|c|}{$\begin{array}{c}\text { Comet parameters evaluated } \\
\text { (Mean } \pm \text { SE) }\end{array}$} & \multirow{2}{*}{$\begin{array}{c}\text { SCE/Cell } \\
\text { (Mean } \pm \text { SE) }\end{array}$} \\
\cline { 3 - 5 } & Tail moment & Tail moment & \\
\hline $\begin{array}{l}\text { Radiation } \\
\text { workers } \\
\text { subjects }\end{array}$ & Female (13) & $0.911 \pm 0.0077$ & $17.78 \pm 0.31$ & $14.59 \pm 0.22$ & $7.68 \pm 0.38$ \\
\cline { 2 - 5 } $\begin{array}{l}\text { Control } \\
\text { Subjects } \\
\text { (Baghdad) }\end{array}$ & Female (8) & $0.921 \pm 0.0069$ & $18.23 \pm 0.30$ & $14.88 \pm 0.27$ & $7.88 \pm 0.41$ \\
\cline { 2 - 5 } & Male (32) & $0.877 \pm 0.0085$ & $14.11 \pm 0.17$ & $11.24 \pm 0.16$ & $6 . \pm 290.21$ \\
\hline
\end{tabular}

The difference in mutation frequency may be because of a different sensitivity to environmental mutagen for males and females. This research result was congruent with another study showing that low ionizing radioactive doses raise the lymphocyte HPRT mutant frequencies [25,27]. DNA ionizing radiation injuries can be observed by electrophoresis of single-cell gel, or by comet test $[28,17]$. The Same method was evaluated in this study on occupationally exposed radiation labors. The comet test is an easy, fast, and accurate test that has been widely applied to identify and repair DNA damage in vitro after exposure to various genotoxic agents and to monitor human bioavailability. [29,30]. In the present study the alkaline comet assay revealed heterogeneity in the level of broken DNA induced by human leukocytes by occupational exposure to ionizing radiation. This finding is consistent with study $[17,6]$. Methods for assessing risks of low levels of exposure to radionuclides and dangerous chemicals for the purpose of protecting human health are well established [31]. Radiation labors chronically exposed to ionizing radiation were tested cytogenetically to determine the frequencies of SCE, in contrast with control individuals. It is well known that the exposure of mammalian cells to ionizing radiation produces a variety of DNA alterations, DNA, protein cross links, and single and double strand breaks 33].Nevertheless, it has been reported that populations exposed to ionizing radiation also present increased SCE frequencies to lymphocytes [32,33].

\section{Conclusion}

The study indicates the possibility of genetically toxic hazards associated with occupational exposure to radiation labors, Al-Amal Hospital for Cancer Management in Baghdad - Iraq, and the results obtained assure the benefit of comet assay as an additional sensitive biomarker in the regular health examination. Of labors professionally exposed to low doses of ionizing radiation. Also indicated that the choice of using sister chromatic changes as useful biomarkers to detect human ionizing radiation exposure was also stated. In the future, it will be important to look at other experimental endpoints of DNA damage, across much larger samples as well as over a longer period of time to better understand the health risks of these exposures.

\section{Compliance with ethical standards}

\section{Acknowledgments}

We thank all laborers at Al-Amal Hospital for cancer administration in Baghdad -Iraq and Ministry of Science and Technology/Central Lab. Directorate, Baghdad, Iraq for support the work and collection the data. 


\section{Disclosure of conflict of interest}

The authors hereby declare that there is no conflict of interest and that we all agreed that the paper be published.

\section{References}

[1] Sari-Minodier I, Orsière T, Auquier P, Martin F, Botta A. Cytogenetic monitoring by use of the micronucleus assay among hospital workers exposed to low doses of ionizing radiation. Mutat. Res. 2007; 629: 111-21.

[2] AbdulSahib K Ali, Wiaam A Al-Amili, Rafid A Abdul-Kareem, Amel J Muttar, Shatha KK, Adil HE. Chromosomal Aberrations and Gene Expression Study in Breast Cancer Patients Undergoing Radiotherapy. 2019.

[3] Fabry L, Lemaire M. Dose response relationship for radiation induced chromosomal aberrations in human lymphocytes in vivo and in vitro. Strahlen therapie. 1986; 162: 63 -67.

[4] Natarajan AT, Vyas RC, Wiegant J, Curado MP. A cytogenetic follow up study of the victims of radiation accident in Goiania (Brazil). Mutat Res. 1991; 247: 103 -111.

[5] Sana B, Soumaya M, Afef D, Faten T, Noutha B, Najib M, Hatem E, Ali S. A Cytogenetic Approach to the Effects of Low Levels of Ionizing Radiation (IR) on the Exposed Tunisian Hospital Workers. International Journal of Occupational. Medicine and Environmental Health. 2013; 26(1): 144 - 154.

[6] Abdulsahib KA, Amel JM, Shath KK, Haider YL, Abullah AK. Assessment of DNA Damage in Peripheral Blood Lymphocytes in Radiation Workers at Al-Twuathia Site by using the sister chromatid exchange and the comet assay. Twelve Arab Conference on the peaceful uses of Atomic Energy, Sharm Elsheikh, Egypt 16-20/5 / 2015.

[7] Hou AW, Yang K, Nyberg F, Hemminik K, Lambert B. HPRT mutant frequency and aromatic DNA adduct level in non-smoking and smoking lung cancer patient and population control. Carcinogenesis. 1999; 20: 437-444.

[8] Curry J, Larissa KG, Glickman BW. Influence of sex, smoking and age on human hprt mutation frequenciesand spectra. Genetics. 1999; 152: 1065-1077.

[9] Muha T Hussein, Abdulsahib K Ali. Study the Effect of Ionizing Radiation on a Sample of workers Using Three Genetic End-Points .Iraqi Jour.of Biotech. 2019; 18(2): 230-236.

[10] Nyberg F, Hou SM, Pershagen G, Lambert B. Influence of diet on the mutant frequency at the hypoxanthineguanine phosphoribosyltransferase (hprt) locus in T-lymphocytes. Carcinogenesis. 2003; 24: 689-696.

[11] Abdulsahib KA, Amel JM, Abdullah AK, Haider YL, Ali HF, Khawla AB. Evaluation of Sister Chromatid Exchanges ,HPRT Gene Mutation Assay in Peripheral Lymphocytes of Radiation Workers at Al-Tuwaitha Site 1st. Sci. Conf. of the Coll. of Science. Baghdad. 2012.

[12] Fekadu Kassie, Wolfram Parzefall, Siegfried Knasmüller. Single cell gel electrophoresis assay: a new technique for human biomonitoring studies.Mutation research. 2000; 463(1): 13-31.

[13] Sram RJ, Podrazilova K, Dejmek J. Single cell gel electrophoresis assay: sensitivity of peripheral white blood cells in human population studies. Mutagenesis. 1998; 13: 99-103.

[14] Olive PL. DNA damage and repair in individual cells: application of the comet assay in radiobiology. Int. J. Radiat. Biol. 1999; 75: 395-405.

[15] Piperakis SM, Visvardis EE, Tassiou AM. Comet assay for nuclear DNA damage. Methods Enzymol. 1999; 300: 184-194.

[16] Maluf SW. Monitoring DNA damage following radiation exposure using cytokinesis-block micronucleus method and alkaline single-cell gel electrophoresis. Clinica. Chimica. Acta. 2004; 347(1-2): 15-24.

[17] Maluf SW, Passosn DF, Bacelar A, Speit G, Erdtmann B. Assessment of DNA damage in lymphocytes of workers exposed to X-radiation using the micronucleus test and the comet assay. Environ. Mol. Mutagen. 2001; 38: 311315.

[18] Sandro Conrad, Julia Künzel. Markus Lobrich Sister chromatid exchanges occur in G2-irradiated cells, Cell Cycle. 2011; 10(2): 222-228.

[19] Beucher A, Birraux J, Tchouandong L, Barton O, Shibata A, Conrad S. ATM and Artemis promote homologous recombination of radiation-induced DNA double-strand breaks in G2. EMBO J. 2009; 28: 3413-3427. 
[20] Cao J, Liu Y, Sun H, Cheng G, Pang X, Zhou Z. Chromosomal aberrations, DNA strand breaks and gene mutations in nasopharyngeal cancer patients undergoing radiation therapy. Mutat. Res. 2002; 504: 85-90.

[21] Kassie F, Parzefall W, Knasmuller S. Single cell gel electrophoresis assay: A new technique for human biomonitoring studies. Mutat. Res. 2000; 463: 13-31.

[22] International Atomic Energy Agency IAEA Cytogenetic analysis for radiation dose assessment. Technical Reports Series. 2001.

[23] Pfeiffer P, Göttlich B, Reichenberger S, Feldmann E, Daza P, Ward JF, Milligan JR, Mullenders LHF, Natarajan AT. DNA lesions and repair. Mutat Res. 1996; 366: 69-80.

[24] Lazutka JR, Lekevicius R, Dedonyte V, Maciuleviciute-Gervers L, Mierauskiene J, Rudaitiene S, Slapsyte G. Chromosomal aberrations and sister chromatids exchanges in Lithuanian populations: effects of occupational and environmental exposures. Mutat Res. 1999; 445: 225-239.

[25] Flavio MA, Aparecido DC, Patricia S, Barry WG. Low doses of gamma ionizing radiation increase HPRT mutant frequencies of TK6 cells without triggering the mutate or phenotype pathway. Genetics and Molecular Biology, 2006; 29(3): 558-561.

[26] Perry P, Evans HJ. Cytological detection of mutagen-carcinogen exposure by sister chromatid exchange. Nature; 1975; 258: 121-125.

[27] Pfeiffer P, Göttlich B, Reichenberger S, Feldmann E, Daza P, Ward JF, Milligan JR, Mullenders LHF, Natarajan AT. DNA lesions and repair. Mutat Res. 1996; 366: 69-80.

[28] Peri N, Saimei H, Irene MJ, Cynthia BT, Lambert B. A comparison of somatic mutational spectra in healthy study populations from Russia, Sweden and USA. Carcinogenesis. 2005; 26(6): 1138-1151.

[29] Collins A, Dusinska M, Franklin M, Somorovska M, Petrovska H, Duthie S, Fillion L, Panayiotidis M, Raslova K, Vaughan N. Comet assay in human biomonitoring studies - reliability, validation and applications. Environ. Mol. Mutagen. 1997; 30: 139-146.

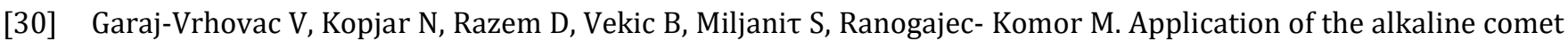
assay in biodosimetry:-assessment of in vivo DNA damage in human peripheral leukocytes after gamma radiation incident. Radiat. Prot. Dosim. 2002; 98: 407-416.

[31] Abdulsahib KA, Amel JM, Shath KK, Haider YL, Abullah AK. Assessment of DNA Damage in Peripheral Blood Lymphocytes in Radiation Workers at Al-Twuathia Site by using the sister chromatid exchange and the comet assay. Twelve Arab Conference on the peaceful uses of Atomic Energy, Sharm Elsheikh , Egypt 16-20/5 / 2015.

[32] Kocher DC, Greim H. An approach to comparative assessments of potential health risks from exposure to radionuclides and hazardous chemicals. Environ. Int. 2002; 27: 663-671.

[33] Lazutka JR, Lekevicius R, Dedonyte V, Maciuleviciute-Gervers L, Mierauskiene J, Rudaitiene S, Slapsyte G. Chromosomal aberrations and sister chromatids exchanges in Lithuanian populations: effects of occupational and environmental exposures. Mutat .Res. 1999; 445: 225-239.

[34] Bozkurt G, Yuksel M, Karabogaz G, Sut N, Savran OF, Palanduz S, Yigitbasi ON. Algunes, C Sister chromatidex changes in lymphocytes of nuclear medicine physicians. Mutat Res. 2003; 535: 205-13. 